Samantha Polly, MD

Complex Medical Dermatology Fellow,

Department of Dermatology, Cleveland

Clinic, Cleveland, $\mathrm{OH}$
Anthony P. Fernandez, MD, PhD

Assistant Professor of Clinical Medicine, Cleveland

Clinic Lerner College of Medicine of Case Western

Reserve University, Cleveland, $\mathrm{OH}$; Director of Medical

Dermatology: W. D. Steck Chair of Clinical Dermatology,

Departments of Dermatology and Pathology, Cleveland

Clinic, Cleveland, $\mathrm{OH}$

\title{
Common skin signs of COVID-19 in adults: An update
}

\section{ABSTRACT}

Cutaneous findings can be clues to diagnosis and infection severity in viral illnesses, including COVID-19. The authors provide an update on the diagnostic and prognostic value of the 5 most common cutaneous abnormalities associated with COVID-19 in adult patients: morbilliform rash, urticaria, vesicles, pseudo-chilblains, and vaso-occlusive lesions.

\section{KEY POINTS}

The common cutaneous abnormalities that occur in COVID-19 patients were recognized early in the pandemic, and evidence concerning their pathogenesis and clinical relevance continues to accumulate.

Urticarial and vesicular eruptions may precede other COVID-19-associated symptoms and, along with morbilliform rashes, are typically associated with overall high survival rates.

The association of pseudo-chilblains with COVID-19 remains controversial, and no definitive evidence linking them to SARS-CoV-2 infection has been reported.

The most worrisome manifestations are vaso-occlusive skin lesions, which most often occur in hospitalized patients with COVID-19 and are associated with a poorer prognosis than other skin lesions.
S EXPERIENCE With CARING for patients A with COVID-19 has accumulated since the onset of the pandemic, so has our understanding of its associated cutaneous manifestations and their clinical implications.

It is beneficial to watch for cutaneous manifestations of COVID-19, both in and out of the hospital. For example, a study of more than 330,000 community-based patients in the United Kingdom ${ }^{1}$ found that patientreported skin rash was associated with positive COVID-19 testing and was more predictive than fever. Additionally, an analysis of 296 hospitalized patients with COVID-19 in the United States ${ }^{2}$ found that mucocutaneous findings were associated with the need for mechanical ventilation, even when adjusted for age, body mass index, and comorbidities.

COVID-19-associated cutaneous abnormalities are often grouped into 5 major categories $(\text { Table } 1)^{3}$ :

- Morbilliform rash (containing macules and papules, resembling measles)

- Urticaria (itchy red welts)

- Vesicles (small blisters)

- Pseudo-chilblains (also known as "COVID toes," painful inflammation of the digits in response to cold)

- Vaso-occlusive lesions (due to thrombosis and occlusion of small arteries, with subsequent ischemia).

\section{MORBILLIFORM RASH: THE MOST COMMON SKIN MANIFESTATION}

Morbilliform eruptions are common in many viral illnesses and were reported in patients with COVID-19 early in the pandemic. ${ }^{4,5}$ International registry data indicate that mor- 


\section{TABLE 1}

Major categories of cutaneous eruptions in COVID-19

prognosis,
with survival
rates of $96.9 \%$
to 97.5\%
Patients
with CoVID-19-
associated
eruptions have
an excellent
prom

\begin{tabular}{|c|c|c|c|c|}
\hline Category & Presentation & Onset rates & $\begin{array}{l}\text { Survival } \\
\text { rates }\end{array}$ & Additional notes \\
\hline Morbilliform & $\begin{array}{l}\text { Pink-erythematous } \\
\text { blanching macules and } \\
\text { papules, commonly on } \\
\text { trunk and lasting } \\
<1 \text { week }\end{array}$ & $\begin{array}{l}\text { Usually within } \\
2 \text { weeks of COVID-19 } \\
\text { symptom onset }\end{array}$ & High $^{a}$ & $\begin{array}{l}\text { Most common cutaneous } \\
\text { finding in confirmed } \\
\text { COVID-19 cases }\end{array}$ \\
\hline Urticarial & $\begin{array}{l}\text { Transient, pruritic } \\
\text { edematous papules and } \\
\text { plaques lasting about } \\
1 \text { week }\end{array}$ & $\begin{array}{l}\text { Can be before } \\
\text { COVID-19 } \\
\text { symptoms }\end{array}$ & High $^{a}$ & $\begin{array}{l}\text { Reported association with } \\
\text { gastrointestinal symptoms }\end{array}$ \\
\hline Vesicular & $\begin{array}{l}\text { Minimally pruritic } \\
\text { vesicular eruption that } \\
\text { can be localized } \\
\text { or diffuse }\end{array}$ & $\begin{array}{l}\text { Can be before } \\
\text { COVID-19 } \\
\text { symptoms }\end{array}$ & High $^{a}$ & $\begin{array}{l}\text { Reported association with } \\
\text { neurologic symptoms }\end{array}$ \\
\hline $\begin{array}{l}\text { Pseudo- } \\
\text { chilblains }\end{array}$ & $\begin{array}{l}\text { Younger, healthy } \\
\text { patients with tender } \\
\text { red-purple papules } \\
\text { affecting toes more } \\
\text { than fingers }\end{array}$ & $\begin{array}{l}\text { Usually within } \\
\text { 2-4 weeks } \\
\text { after COVID-19 } \\
\text { symptom onset } \\
\text { Recently reported in } \\
\text { "long-haulers" }\end{array}$ & High $^{a}$ & $\begin{array}{l}\text { Association with SARS- } \\
\text { CoV-2 infection is debated }\end{array}$ \\
\hline Vaso-occlusive & $\begin{array}{l}\text { Hospitalized patients } \\
\text { with retiform purpura, } \\
\text { livedo racemosa, acral } \\
\text { necrosis, or sacral ulcers }\end{array}$ & $\begin{array}{l}\text { Usually within } 2 \\
\text { weeks of COVID-19 } \\
\text { symptom onset }\end{array}$ & Lower $^{\text {b }}$ & $\begin{array}{l}\text { Linked to systemic vascular } \\
\text { thrombosis }\end{array}$ \\
\hline
\end{tabular}

billiform eruptions are the most common cutaneous manifestation in patients with laboratory-confirmed COVID-19. ${ }^{6}$ Typical clinical features include a generalized, symmetric maculopapular rash with pruritus (Figure 1).?

Patients with COVID-19-associated morbilliform eruptions have an excellent prognosis, with survival rates of $96.9 \%^{8}$ to $97.5 \% .^{3}$

\section{URTICARIA CAN BE THE FIRST SIGN OF COVID-19}

Urticaria is also common in COVID-19. The clinical features do not appear to differ from those of idiopathic urticaria and typically consist of generalized pruritic wheals. ${ }^{9,10}$ On average, urticaria lasts less than 1 week $^{11}$ and is associated with relatively mild disease and survival rates of $97.8 \%{ }^{6}$ to $98.2 \% .^{3}$

Histologic features also mimic those of idiopathic urticaria and thus limit the value of skin biopsy. ${ }^{9,10}$ However, urticarial vasculitis has been described in association with $\mathrm{CO}$ VID-19, suggesting that biopsy should be considered in patients with persistent urticarial plaques with associated purpura. ${ }^{12}$

Interestingly, in a systematic review of 895 patients with COVID-19, ${ }^{13} 105$ (12\%) had urticarial lesions, and in $17(16 \%)$ of these 105 the urticaria began before the onset of the other COVID-19 symptoms, suggesting that it can be a clue to diagnosis in appropriate clinical settings and can help 


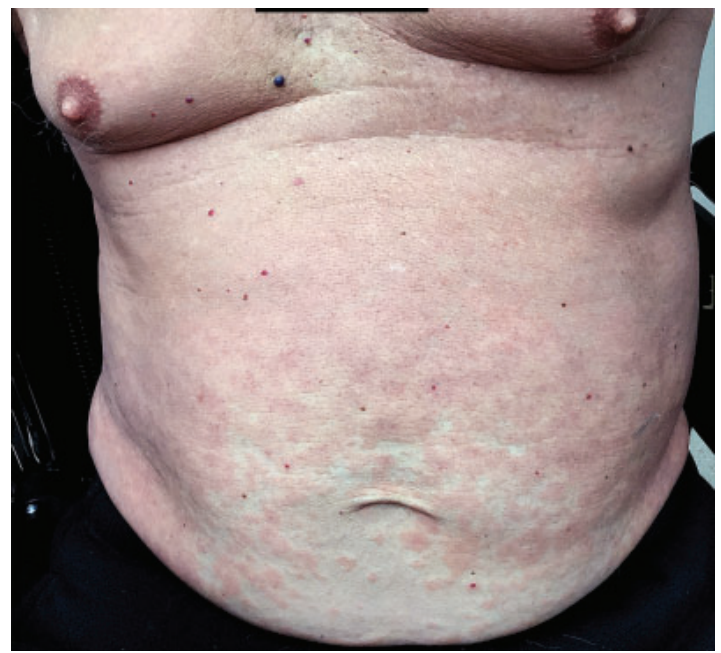

Figure 1. Morbilliform rash in COVID-19. A 77-year-old man was hospitalized with COVID-19 and developed bilateral pneumonia and acute hypoxic respiratory failure. Four days after discharge, while continuing to have low-grade fevers, he developed pink papules confluent over the trunk and extremities consistent with a morbilliform eruption.

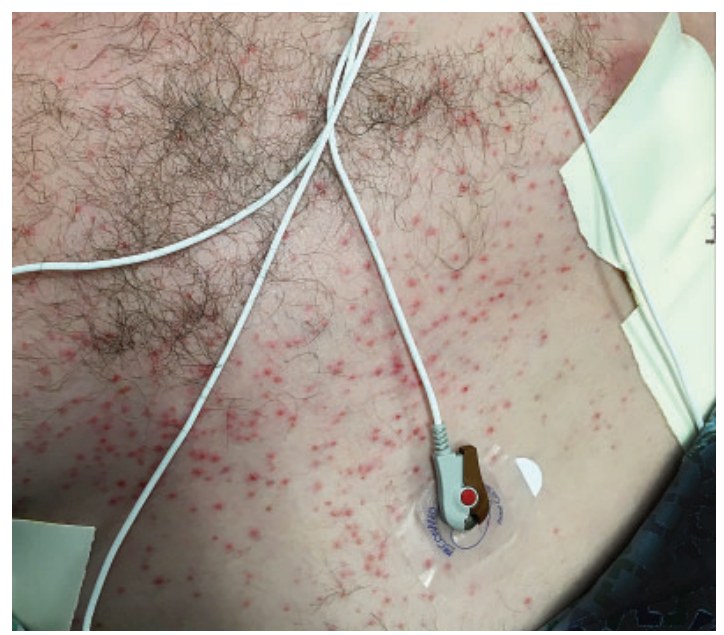

Figure 3. Vesicular eruption in COVID-19. A 52-year-old man developed a vesiculopustular eruption on his trunk during hospitalization for COVID-19 requiring intensive care unit admission and mechanical ventilation for acute respiratory failure due to respiratory distress syndrome. He recovered and was eventually discharged.

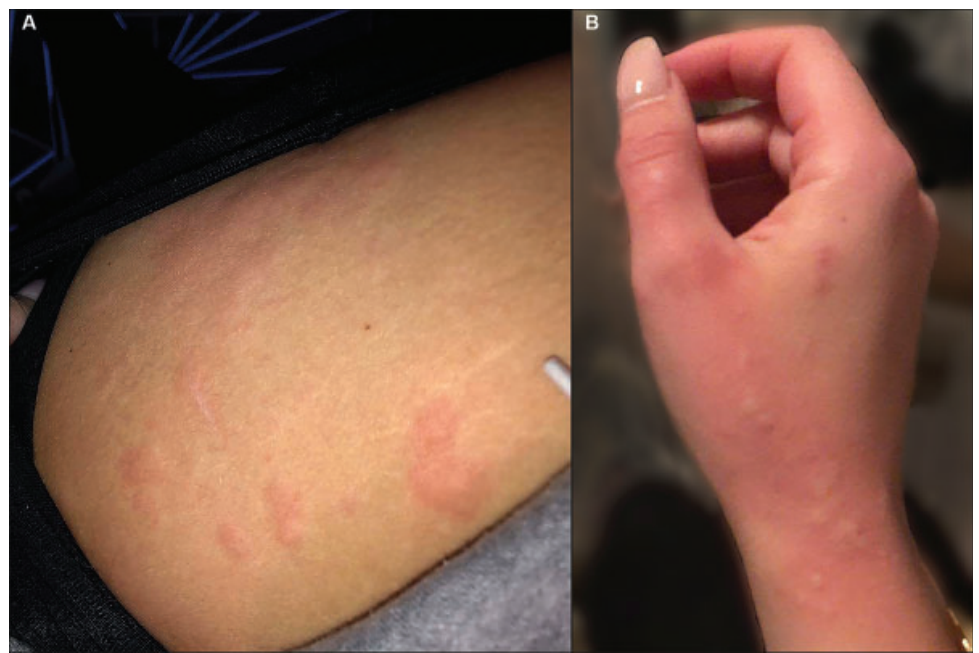

Figure 2. Urticarial lesions preceding COVID-19 diagnosis. A 21-year-old woman with no known previous skin problems developed urticarial lesions in various locations, including the thighs (A) and hands (B) several days before testing positive for COVID-19 as part of a routine screening protocol. She subsequently experienced systemic symptoms including palpitations, cough, fatigue, and loss of taste and smell, but was able to be managed on an outpatient basis with supportive care.

guide early testing (Figure 2). ${ }^{13}$ Additionally, an analysis of 200 patients with COVID-19 with cutaneous manifestations ${ }^{14}$ found a significant association between urticaria and gastrointestinal symptoms, which could assist clinicians in their anticipatory management.

\section{VESICLES CAN ALSO BE THE FIRST SIGN OF COVID-19}

Initially described as "varicella-like," 15 vesicular eruptions in COVID-19 have been described in both localized and diffuse distributions. The localized pattern is characterized by monomorphic vesicles in the same stage of evolution that are confined to the trunk (Figure 3 ). But the diffuse pattern may be more common. A cohort study ${ }^{16}$ reported that it accounted for $18(75 \%)$ of 24 cases. The diffuse pattern consists of polymorphic papules, vesicles, and pustules that develop simultaneously on the trunk and spread distally, sometimes involving the palms and soles. Lesions tend to resolve after about 8 days without scarring. ${ }^{15}$
An analysis of 200 patients with COVID-19 with cutaneous manifestations found a significant association

\section{between} urticaria and gastrointestinal symptoms 


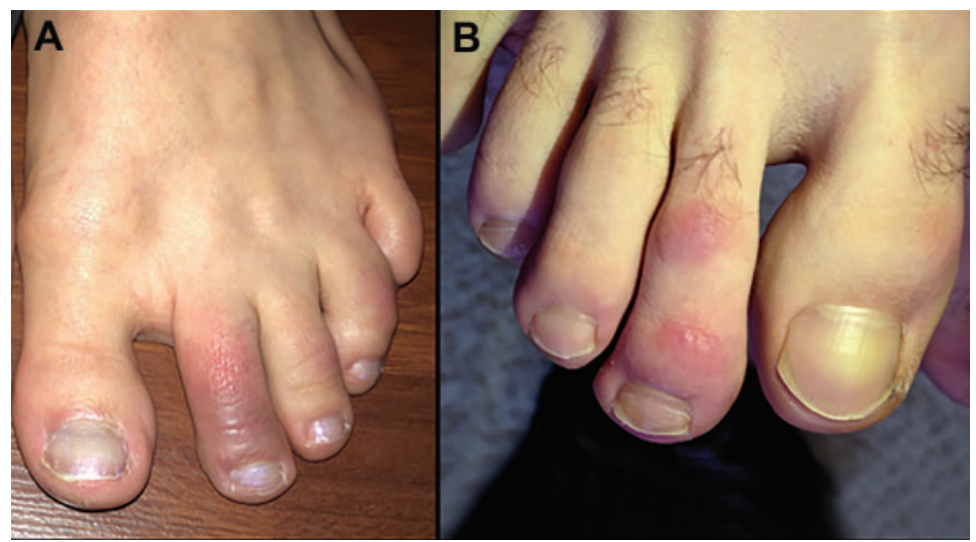

Figure 4. Pseudo-chilblains ("COVID toes"). (A) A 24-yearold woman developed painful erythematous and violaceous macules involving her dorsal toes after testing positive for COVID-19. She had no other symptoms. (B) A young adult man sought care in a telemedicine encounter after developing painful, erythematous papules on his toes. His eventual COVID-19 status is unknown.

Lesional skin biopsies reveal histologic features consistent with viral exanthems, namely vacuolar degeneration of the basal epidermal layer with occasional dyskeratotic keratinocytes and superficial dermal inflam-

Information is accumulating about pernio-like lesions in 'long-hauler' COVID-19 patients mation..$^{15}$ However, some reports describe prominent keratinocyte acantholysis contributing to formation of intraepidermal vesicles, which is a relatively unusual histologic finding. ${ }^{17}$ Additionally, while there have been reports of SARS-CoV-2 spike proteins detected with immunohistochemistry in sweat glands and dermal endothelial cells in skin biopsies from COVID-19 patients, 2 studies of COVID-19-associated vesicular rashes detected no SARS-CoV-2 in vesicular fluid by reverse transcriptase polymerase chain reaction testing. ${ }^{16-18}$

Like urticaria, vesicular eruptions were also commonly noted before other COVID-19 symptoms (in $8.5 \%$ to $15 \%{ }^{13}$ of cases of COVID-19-associated urticaria) in multiple studies, and therefore may similarly provide an indication for COVID-19 testing and isolation in the appropriate clinical context. ${ }^{3,14,19}$ Additionally, a systematic review ${ }^{8}$ reported a possible link between vesicular eruptions and neurologic symptoms including headache, dysgeusia, irritability, and confusion. Like those with morbilliform rash or urticar-

ia, patients with COVID-19 with vesicular eruptions have high survival rates $\left(96.1 \%^{3}\right.$ to $\left.96.6 \%^{8}\right)$

\section{PSEUDO-CHILBLAINS: LINK TO COVID-19 DEBATED}

Although pernio-like acral lesions (Figure 4) were the first cutaneous manifestations to generate significant attention, whether they are truly linked to COVID-19 has been debated.

Challenging the link are strikingly low rates of positive COVID-19 testing in affected patients, as well as results of several studies $^{20-24}$ that suggest these lesions are most consistent with typical perniosis, with an increased incidence related to changes in daily routine (eg, quarantining, working from home) during the pandemic rather than infection with SARS-CoV-2. Additionally, a systematic review ${ }^{8}$ found that pre-existing rheumatologic conditions were more common in patients with presumed COVID-19-related pernio-like lesions, raising the possibility that underlying diagnoses contributed to development of the acral lesions.

However, proponents of the association with COVID-19 point to "outbreaks" of chilblain-like lesions corresponding to $\mathrm{CO}$ VID-19 waves and propose that an efficient, type I interferon-driven antiviral response could induce pernio-like lesions and suppress both symptoms and confirmatory testing. ${ }^{25-29}$ Interestingly, information is accumulating about pernio-like lesions in "long-hauler" patients, with a significant association reported between persistent cutaneous and extracutaneous symptoms. ${ }^{30-32}$

While the debate continues, if these lesions are truly a COVID-19 manifestation, they are fortunately associated with high survival rates $\left(96.4 \%^{6}\right.$ to $\left.98.7 \%^{3}\right)$ and few or no systemic symptoms. 33,34

\section{VASO-OCCLUSIVE LESIONS ARE ASSOCIATED WITH HIGHER RISK}

Vaso-occlusive lesions (Figure 5) have been reported in patients with COVID-19 with varied clinical presentations, including fixed livedo racemosa, retiform purpura, and acral 
ischemia, which may be clinically confused with COVID toes. ${ }^{19}$ These lesions are most commonly seen in hospitalized patients with moderate to severe COVID-19 ${ }^{19}$ and are associated with higher risks of severe pneumonia and intensive care unit admission and relatively low survival rates $\left(78.9 \%{ }^{3}\right.$ to $\left.81.8 \%{ }^{8}\right)$.

Similar patterns of microvascular thrombosis have been found in skin biopsies and pulmonary tissue of COVID-19 patients with vaso-occlusive cutaneous lesions, suggesting that this manifestation could be a marker of systemic microvascular injury. ${ }^{35}$ Additionally, systemic thrombotic events including deep vein thrombosis and pulmonary embolism have been reported in patients with retiform and necrotic lesions, with rates as high as $64 \%$. ${ }^{6,36}$ Whether early recognition of these lesions can prompt treatment decisions that decrease systemic thrombotic events or increase overall survival requires further research.

\section{OTHER CUTANEOUS FINDINGS}

Other cutaneous findings that have been reported with COVID-194,7,37-39 include oral lesions; reactivation of viral infections; rash resembling symmetrical drug-related intertriginous and flexural exanthema; small-vessel vasculitis; cutaneous hyperesthesia; papulosquamous eruptions; and erythema nodosumlike lesions.

Oral lesions. A study of 666 patients $^{40}$ reported various oral mucosal findings in 78 (26\%) of 304 patients who had mucocutaneous manifestations, and the authors hypothesized that lesions in the mouth may be underreported due to contact precautions and assisted ventilation that limits examination of the oral mucosa. ${ }^{40}$

Reactivation of herpes simplex virus (HSV) and varicella-zoster virus (VZV) infections has been reported in conjunction with COVID-19 infection. A cross-sectional

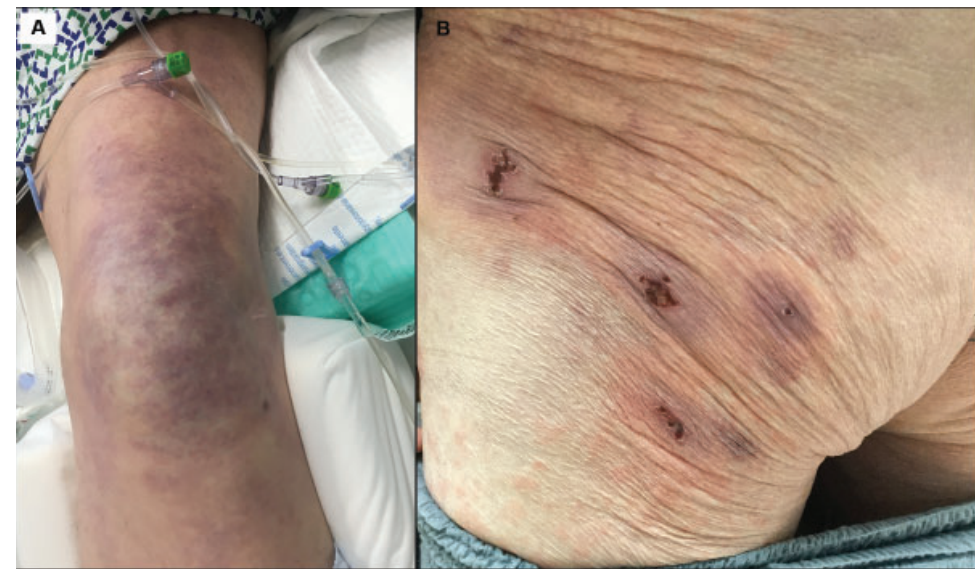

Figure 5. Vaso-occlusive lesions in COVID-19. (A) A 62-yearold man with COVID-19 developed an irregular, mottled, purpuric patch on his knee extending onto his thigh during an extended hospitalization complicated by septic shock and acute respiratory failure requiring mechanical ventilation. He died of his illness 3.5 weeks after admission.

(B) A 77-year-old man (also described in Figure 1) developed purpuric patches with central hemorrhagic crusts on the left buttock shortly after hospitalization for COVID-19.

study of nearly 900 patients with COVID-19 found a significantly higher prevalence of HSV-1 and VZV than in the hospital population, even when adjustments were made for numerous comorbidities. ${ }^{41}$ Some reports suggest that HSV reactivation may be associated with more severe COVID-19 infection, including acute respiratory distress syndrome and viremia, ${ }^{42,43}$ but the prognostic implications of treating these reactivations has not yet been robustly investigated.

Acknowledgment: The authors would like to thank Janine Sot, MBA, for her help and expertise in preparing the figures in this article.

\section{DISCLOSURES}

Dr. Fernandez reports consulting for Abbvie Pharmaceuticals, Boehringer Ingelheim, Bristol-Myers Squibb, Mallinckrodt, Novartis, and UCB; teaching and speaking (non-promotional) for Abbvie Pharmaceuticals, Kyowa Kirin, Mallinckrodt, and Novartis; research/independent contracting for Abbvie Pharmaceuticals, Mallinckrodt, Novartis, and Pfizer; and work as advisor or review panel participant for Abbvie Pharmaceuticals. Dr. Polly reports no relevant financial relationships which, in the context of her contributions, could be perceived as a potential conflict of interest.

\section{REFERENCES}

1. Visconti A, Bataille V, Rossi N, et al. Diagnostic value of cutaneous manifestation of SARS-CoV-2 infection. Br J Dermatol 2021; 184(5):880-887. doi:10.1111/bjd.19807

2. Rekhtman S, Tannenbaum R, Strunk A, et al. Eruptions and related clinical course among 296 hospitalized adults 
4. Galván Casas C, Català A, Carretero Hernández G, et al. Classification of the cutaneous manifestations of COVID-19: a rapid prospective nationwide consensus study in Spain with 375 cases. Br J Dermatol 2020; 183(1):71-77. doi:10.1111/bjd.19163

5. Sachdeva M, Gianotti R, Shah M, et al. Cutaneous manifestations of COVID-19: Report of three cases and a review of literature. J Dermatol Sci 2020; 98(2):75-81. doi:10.1016/j.jdermsci.2020.04.011

6. Freeman EE, McMahon DE, Lipoff JB, et al. The spectrum of COVID-19-associated dermatologic manifestations: an international registry of 716 patients from 31 countries. J Am Acad Dermatol 2020; 83(4):1118-1129. doi:10.1016/j.jaad.2020.06.1016

7. Genovese G, Moltrasio C, Berti E, Marzano AV. Skin manifestations associated with COVID-19: current knowledge and future perspectives. Dermatology 2021; 237(1):1-12. doi:10.1159/000512932

8. Jamshidi P, Hajikhani B, Mirsaeidi M, Vahidnezhad H, Dadashi M, Nasiri MJ. Skin manifestations in COVID-19 patients: are they indicators for disease severity? A systematic review. Front Med (Lausanne) 2021. Published 2021 Feb 16. doi:10.3389/fmed.2021.634208

9. Rongioletti F, Ferreli C, Sena P, Caputo V, Atzori L. Clinicopathologic correlations of COVID-19-related cutaneous manifestations with special emphasis on histopathologic patterns. Clin Dermatol 2021; 39(1):149-162. doi:10.1016/j.clindermatol.2020.12.004

10. Almeida G, Arruda S, Marques E, Michalany N, Sadick N. Presentation and management of cutaneous manifestations of COVID-19. J Drugs Dermatol 2021; 20(1):76-83. doi:10.36849/JDD. 5676

11. Algaadi SA. Urticaria and COVID-19: a review. Dermatol Ther 2020; 33(6):e14290. doi:10.1111/dth.14290

12. de Perosanz-Lobo D, Fernandez-Nieto D, Burgos-Blasco $P$ et al. Urticarial vasculitis in COVID-19 infection: a vasculopathy-related symptom? J Eur Acad Dermatol Venereol 2020; 34(10):e566-e568. doi:10.1111/jdv.16713

13. Gisondi P, Di Leo S, Bellinato F, Cazzaniga S, Piaserico S, Naldi L. Time of onset of selected skin lesions associated with COVID-19: a systematic review. Dermatol Ther (Heidelb) 2021; 11(3):695-705. doi:10.1007/s13555-021-00526-8

14. Marzano AV, Genovese G, Moltrasio C, et al. The clinical spectrum of COVID-19-associated cutaneous manifestations: an Italian multicenter study of 200 adult patients. J Am Acad Dermatol 2021; 84(5):1356-1363. doi:10.1016/j.jaad.2021.01.023

15. Marzano AV, Genovese G, Fabbrocini G, et al. Varicellalike exanthem as a specific COVID-19-associated skin manifestation: multicenter case series of 22 patients. J Am Acad Dermatol 2020; 83(1):280-285. doi:10.1016/j.jaad.2020.04.044

16. Fernandez-Nieto D, Ortega-Quijano D, Jimenez-Cauhe J, et al. Clinical and histological characterization of vesicular COVID-19 rashes: a prospective study in a tertiary care hospital. Clin Exp Dermatol 2020; 45(7):872-875. doi:10.1111/ced.14277

17. Mahé A, Birckel E, Merklen C, et al. Histology of skin lesions establishes that the vesicular rash associated with COVID-19 is not 'varicella-like'. J Eur Acad Dermatol Venereol 2020; 34(10):e559-e561. doi:10.1111/jdv.16706

18. Liu J, Li Y, Liu L, et al. Infection of human sweat glands by SARS-CoV-2. Cell Discov 2020; 6(1):84. doi:10.1038/s41421-020-00229-y

19. Galván Casas C, Català A, Carretero Hernández G, et al. Classification of the cutaneous manifestations of COVID-19: a rapid prospective nationwide consensus study in Spain with 375 cases. Br J Dermatol 2020; 183(1):71-77. doi:10.1111/bjd.19163

20. McCleskey PE, Zimmerman B, Lieberman A, et al. Epidemiologic analysis of chilblains cohorts before and during the COVID-19 pandemic. JAMA Dermatol 2021; 157(8):947-953. doi:10.1001/jamadermatol.2021.2120

21. Herman A, Peeters C, Verroken A, et al. Evaluation of chilblains as a manifestation of the COVID-19 pandemic. JAMA Dermatol 2020; 156(9):998-1003. doi:10.1001/jamadermatol.2020.2368

22. Baeck M, Peeters C, Herman A. Chilblains and COVID-19: further evidence against a causal association. J Eur Acad Dermatol Venereol 2021; 35(1):e2-e3. doi:10.1111/jdv.16901

23. Baeck M, Herman A. COVID toes: where do we stand with the current evidence? Int J Infect Dis 2021; 102:53-55. doi:10.1016/j.ijid.2020.10.021

24. Le Cleach L, Dousset L, Assier $\mathbf{H}$, et al. Most chilblains observed during the COVID-19 outbreak occur in patients who are negative for COVID-19 on polymerase chain reaction and serology testing. Br J Dermatol 2020; 183(5):866874. doi:10.1111/bjd.19377

25. Giraud-Kerleroux L, Mongereau M, Cassius C, et al. Detection of a second outbreak of chilblain-like lesions during COVID-19 pandemic through teledermatology. J Eur Acad Dermatol Venereol 2021; 35(9):e556-e558. doi:10.1111/jdv.17378

26. Hubiche T, Le Duff F, Fontas E, Rapp J, Chiaverini C, Passeron $\mathrm{T}$. Relapse of chilblain-like lesions during the second wave of the COVID-19 pandemic: a cohort follow-up. Br J Dermatol 2021; 185(4):858-859. doi:10.1111/bjd.20584

27. Hubiche T, Cardot-Leccia N, Le Duff F, et al. Clinical, laboratory, and interferon-alpha response characteristics of patients with chilblain-like lesions during the COVID-19 pandemic. JAMA Dermatol 2021; 157(2):202-206. doi:10.1001/jamadermatol.2020.4324

28. Cappel MA, Cappel JA, Wetter DA. Pernio (chilblains), SARS-CoV-2, and COVID toes unified through cutaneous and systemic mechanisms. Mayo Clin Proc 2021; 96(4):989-1005. doi:10.1016/j.mayocp.2021.01.009

29. Arkin LM, Moon JJ, Tran JM, et al. From your nose to your toes: a review of severe acute respiratory syndrome coronavirus 2 pandemic-associated pernio. J Invest Dermatol 2021; 141(12):2791-2796. doi:10.1016/j.jid.2021.05.024

30. McMahon DE, Gallman AE, Hruza GJ, et al. Long COVID in the skin: a registry analysis of COVID-19 dermatological duration. Lancet Infect Dis 2021; 21(3):313-314. doi:10.1016/S1473-3099(20)30986-5

31. Mehta P, Bunker CB, Ciurtin C, et al. Chilblain-like acral lesions in long COVID-19: management and implications for understanding microangiopathy. Lancet Infect Dis 2021; 21(7):912. doi:10.1016/S1473-3099(21)00133-X

32. Moghadam P, Frumholtz $L$, Jaume $L$, et al. Frequency of relapse and persistent cutaneous symptoms after a first episode of chilblain-like lesion during the COVID-19 pandemic. J Eur Acad Dermatol Venereol 2021; 35(9):e566e568. doi:10.1111/jdv.17393

33. Piccolo V, Neri I, Filippeschi $\mathbf{C}$, et al. Chilblain-like lesions during COVID-19 epidemic: a preliminary study on 63 patients. J Eur Acad Dermatol Venereol 2020; 34(7):e291293. doi:10.1111/jdv.16526

34. de Masson A, Bouaziz JD, Sulimovic L, et al. Chilblains is a common cutaneous finding during the COVID-19 pandemic: A retrospective nationwide study from France. J Am Acad Dermatol 2020; 83(2):667-670. doi:10.1016/j.jaad.2020.04.161

35. Magro C, Mulvey JJ, Berlin D, et al. Complement associated microvascular injury and thrombosis in the pathogenesis of severe COVID-19 infection: a report of five cases. Transl Res 2020; 220:1-13. doi:10.1016/j.trsl.2020.04.007 
36. Droesch C, Do MH, DeSancho M, Lee EJ, Magro C, Harp J. Livedoid and purpuric skin eruptions associated with coagulopathy in severe COVID-19. JAMA Dermatol 2020; 156(9):1-3. doi:10.1001/jamadermatol.2020.2800

37. Mahé A, Birckel E, Krieger S, Merklen C, Bottlaender L. A distinctive skin rash associated with coronavirus disease 2019? J Eur Acad Dermatol Venereol 2020; 34(6): e246-e247. doi:10.1111/jdv.16471

38. Krajewski PK, Maj J, Szepietowski JC. Cutaneous hyperaesthesia in SARS-CoV-2 infection: rare but not unique clinical manifestation. Acta Derm Venereol 2021; 101(1):adv00366. Published 2021 Jan 5.

doi:10.2340/00015555-3729

39. Kuriyama Y, Shimizu A, Oka H, et al. Erythema nodosumlike eruption in coronavirus disease 2019: a case report and literature review of Asian countries. J Dermatol 2021; 48(10):1588-1592. doi:10.1111/1346-8138.16071

40. Nuno-Gonzalez A, Martin-Carrillo P, Magaletsky K, et al. Prevalence of mucocutaneous manifestations in 666 patients with COVID-19 in a field hospital in Spain: oral and palmoplantar findings. Br J Dermatol 2021; 184(1): 184-185. doi:10.1111/bjd.19564

41. Katz J, Yue $\mathbf{S}$, Xue W. Herpes simplex and herpes zoster viruses in COVID-19 patients. Ir J Med Sci 2021; 1-5. doi:10.1007/s11845-021-02714-z

42. Le Balc'h P, Pinceaux K, Pronier C, Seguin P, Tadié JM, Reizine $F$. Herpes simplex virus and cytomegalovirus reactivations among severe COVID-19 patients. Crit Care 2020; 24(1):530. doi:10.1186/s13054-020-03252-3

43. Xu R, Zhou Y, Cai L, et al. Co-reactivation of the human herpesvirus alpha subfamily (herpes simplex virus- 1 and varicella zoster virus) in a critically ill patient with $\mathrm{CO}$ VID-19. Br J Dermatol 2020; 183(6):1145-1147. doi:10.1111/bjd.19484

Address: Anthony P. Fernandez, MD, PhD, Department of Dermatology, A61, Cleveland Clinic, 9500 Euclid Avenue, Cleveland, $\mathrm{OH}$ 44195; fernana6@ccf.org 